\title{
A new form of the mole vole Ellobius tancrei Blasius, 1884 (Mammalia, Rodentia) with the lowest chromosome number
}

\author{
Irina Bakloushinskaya', Svetlana A. Romanenko², Natalia A. Serdukova², \\ Alexander S. Graphodatsky², Elena A. Lyapunova'
}

I Koltzov Institute of Developmental Biology, Russian Academy of Sciences, Moscow, Russia, 26 Vavilov str. Moscow, 119334, Russia 2 Institute of Molecular and Cellular Biology Siberian Branch, Russian Academy of Sciences, 8/2 Av. Acad. Lavrentev, Novosibirsk, 630090, Russia

Corresponding author: Irina Bakloushinskaya (irina.bakl@gmail.com)

Academic editor: E. Gornung | Received 18 April 2013 | Accepted 23 May 2013 | Published 11 June 2013

Citation: Bakloushinskaya I, Romanenko SA, Serdukova NA, Graphodatsky AS, Lyapunova EA (2013) A new form of the mole vole Ellobius tancrei Blasius, 1884 (Mammalia, Rodentia) with the lowest chromosome number. Comparative Cytogenetics 7(2): 163-169. doi: 10.3897/CompCytogen.v7i2.5350

\begin{abstract}
The subterranean mole vole, Ellobius tancrei, with a specific variability in autosomes $(2 \mathrm{n}=31-54)$ and unusual sex chromosomes (XX in males and females), represents an amazing model for studying the role of chromosome changes in speciation. New materials from the upper reaches of the Surkhob River in the Pamiro-Alay mountains resulted in the discovery of a new form with $2 \mathrm{n}=30$. The application of Zoo-FISH and G-banding methods allowed the detection of 13 pairs of autosomes as Robertsonian metacentrics originated after fusions of acrocentrics of an assumed ancestral karyotype of $E$. tancrei with $2 \mathrm{n}=54$. The sex chromosomes (XX, in both sexes) and one pair of acrocentric autosomes are the only acrocentrics in this karyotype, and the set with $2 \mathrm{n}=30$ possesses the lowest possible chromosome number among populations of E. tancrei.
\end{abstract}

\section{Keywords}

speciation, mole voles, Ellobius, Robertsonian rearrangements, chromosome painting, Cricetidae

Copyright Irina Bakloushinskaya et al. This is an open access article distributed under the terms of the Creative Commons Attribution License 3.0 (CC-BY), which permits unrestricted use, distribution, and reproduction in any medium, provided the original author and source are credited. 


\section{Introduction}

Naturally occurring chromosome variability is essential for understanding the disputed role of chromosome changes in speciation (White 1978, King 1993). A Robertsonian $(\mathrm{Rb})$ translocation is a chromosome rearrangement involving the centric fusion of two acrocentric chromosomes to form a single metacentric chromosome, and it is one of the most frequent events in mammalian karyotype evolution (Slijepcevic 1998, RuizHerrera et al. 2012). Well-studied cases of extensive Robertsonian variation in species such as the house mouse, Mus musculus domesticus Schwarz et Schwarz, 1943 (Gropp et al. 1969, Piálek et al. 2005), the common shrew, Sorex araneus Linnaeus, 1758 (Ford et al. 1957, Wójcik et al. 2003), or the mole vole Ellobius tancrei (Lyapunova et al. 1980, 2010) have their own specific features. All these species are widely distributed; for example, house mice are distributed all over the globe due to human activity. Mice and shrews include a lot of races within their ranges, but $E$. tancrei has 2 n $=54$ over most of the distribution range and a great variety in chromosome numbers ( 2 n from 53 to 31), which is restricted to a limited area in the Pamiro-Alay, with only single non-homologous translocations $(2 n=53)$ recorded outside, in the Tien Shan mountains (Lyapunova et al. 1985). An amazing feature of mole voles is their subterranean way of life. Living underground preserves mole voles from predators, restricts spreading, and promotes their sociality. The last two factors may contribute to a rapid fixation of chromosome translocations due to more or less permanent monogamous bonds (our unpublished data).

Thorough analysis based on G-banding revealed a complicated structure of chromosome variability in the Surkhob River valley (Pamiro-Alay), where forms with the same chromosome numbers have different sets of Rb metacentrics. It was concluded that the variability was produced by hybridisation, as well as chain fusions (Bakloushinskaya, Lyapunova 2003). New field explorations and applying a fluorescence in situ hybridisation (Zoo-FISH) approach have revealed a case of monobrachial homology in this region too (Bakloushinskaya et al. 2010), and raised a question of natural limits for fusions. In numerous field explorations, we were unable to find additional animals at the area where a single specimen with $2 \mathrm{n}=31$ was collected (Lyapunova et al. 1980). The surrounding areas are inhabited by the form with $2 \mathrm{n}=32$, and that is why the specimen was considered by us, for a long time, as a case of a single mutation. The main aim of this study was to investigate suitable mole vole areas in the upper reaches of the Surkhob River and determine the structure of karyotypes for discovered animals.

\section{Material and methods}

Five animals (two females and three males) from two colonies were captured by live traps (Golov 1954) on the northern bank of the Surkhob River in Pamiro-Alay $\left(39^{\circ} 15.37^{\prime} \mathrm{N}, 71^{\circ} 20.59^{\prime} \mathrm{E}, 900 \mathrm{~m}\right.$ above sea level) in April, 2010.

Chromosomes from bone marrow (Ford, Hamerton 1956) were prepared from all animals; tissues of three specimens were used for tissue culturing. Fibroblast cell 
lines were prepared as previously described (Sitnikova et al. 2007). Full sets of paints derived from flow-sorted chromosomes of the field vole Microtus agrestis Linnaeus, 1761 (Sitnikova et al. 2007) were used. FISH was performed according to previously published protocols (Yang et al. 1999; Graphodatsky et al. 2000). G-banding was carried out for all metaphase chromosomes prior to FISH using trypsin treatments (Seabright 1971).

Images were captured using VideoTesT-FISH 2.0. and VideoTesT-Karyo 3.1. (VideoTesT) or Case Data Manager 6.0 (Applied Spectral Imaging Inc., ASI) software with either a ProgRes CCD (Jenoptik) or ASI CCD camera, respectively, mounted on an Axioskop 2 plus (Zeiss) microscope with filter sets for DAPI, FITC, and rhodamine. Hybridisation signals were assigned to specific chromosome regions defined by GTG-banding patterns previously photographed and captured with the CCD camera. All images were processed using PaintShop Photo Pro X2 (Corel).

\section{Results}

We analysed the structure of karyotypes obtained by direct methods from bone marrow and from cultures. It is known that spontaneous chromosome aberrations may appear in cell cultures (Clare 2012), so it was necessary to control the karyotype structure by a direct method. Karyotypes of all animals contained 30 chromosomes (Fig. 1 ), and at least 30 plates were counted for each specimen. One pair of submetacentric chromosomes (N 7) is typical for E. tancrei and distinguishes it from the chromosomally stable sibling species E. talpinus Pallas, 1770. As we reported recently, these chromosomes obtained evolutionary new centromeres (Bakloushinskaya et al. 2012). There are also 12 pairs of $\mathrm{Rb}$ metacentrics, one pair of acrocentric chromosomes, and the sex chromosomes XX, which are acrocentric in both sexes. Each of the fifteen chromosome painting probes of the field vole, Microtus agrestis, (MAG 2, 4, 6, 10-13, 15, 16, 18-24) delineated one region in the $E$. tancrei, 2 n $=30$ karyoform; eight probes (MAG $3,5,7-9,13,14,17)$ each delineated two chromosome segments; and the MAG 1 probe delineated four chromosome segments. The only MAG X probe showed signals on both male and female X chromosomes; the MAG Y probes has not produced any specific signal. In total, the $21 \mathrm{MAG}$ autosomal probes revealed 35 conserved segments in the genome, which corresponds to the genome composition of typical E. tancrei, $2 \mathrm{n}=54$ (Bakloushinskaya et al. 2012). The comparison revealed a complete homology between acrocentrics and corresponding $\mathrm{Rb}$ metacentrics. The smallest $\mathrm{Rb}$ metacentric $[\mathrm{Rb}(24.26)$, Fig. 1] has never been detected in karyotypes of other chromosomal forms, including the form with the low chromosome number, $2 \mathrm{n}=32$, which inhabits the northern bank of the Surkhob River (Bakloushinskaya, Lyapunova 1990). Acrocentric chromosomes involved in the translocation were determined by G-banding as chromosomes number 24 and 26, according to the new nomenclature developed for $E$. tancrei, $2 \mathrm{n}=54$ (Bakloushinskaya et al. 2012), and confirmed by applying Zoo-FISH probes MAG18 and MAG24 (Fig. 2). 


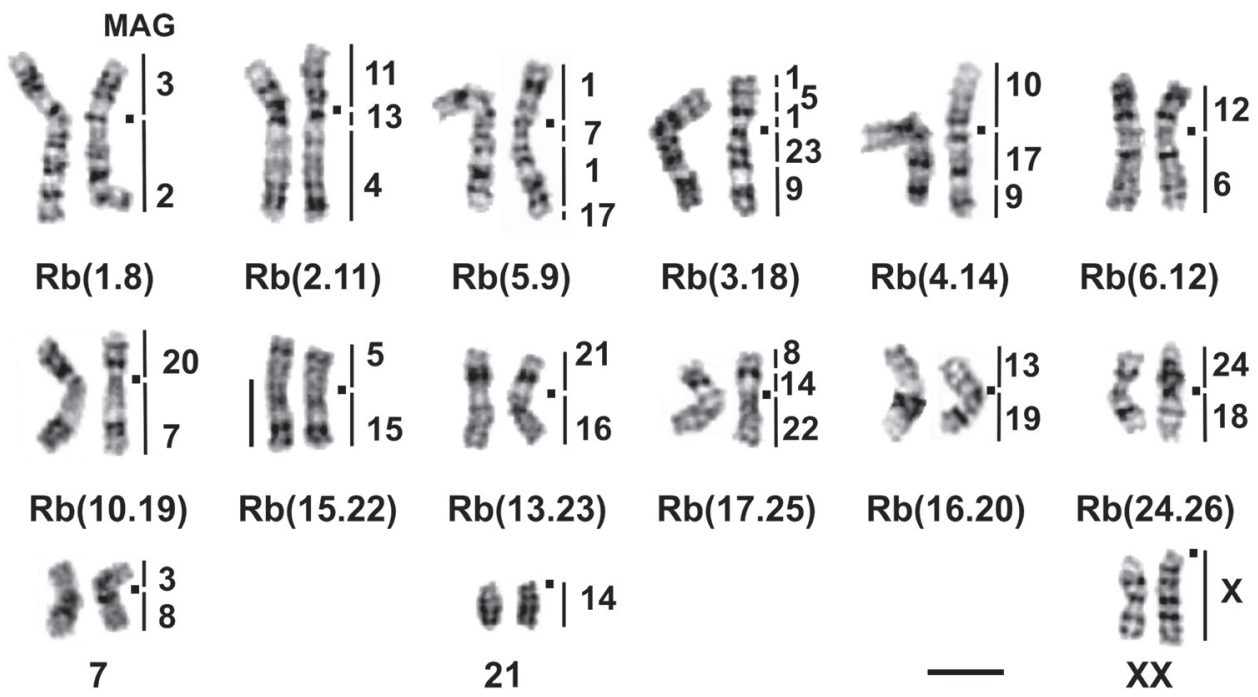

Figure I. G-banded karyotype of E. tancrei, 2 n = $30(25618 \precsim$ ঐ). The chromosome nomenclature follows Bakloushinskaya et al. (2012). Black squares mark the positions of centromeres. Vertical black bars and the numbers beside them mark the localisation of $M$. agrestis (MAG) chromosome segments. Bar $=10 \mu \mathrm{m}$.

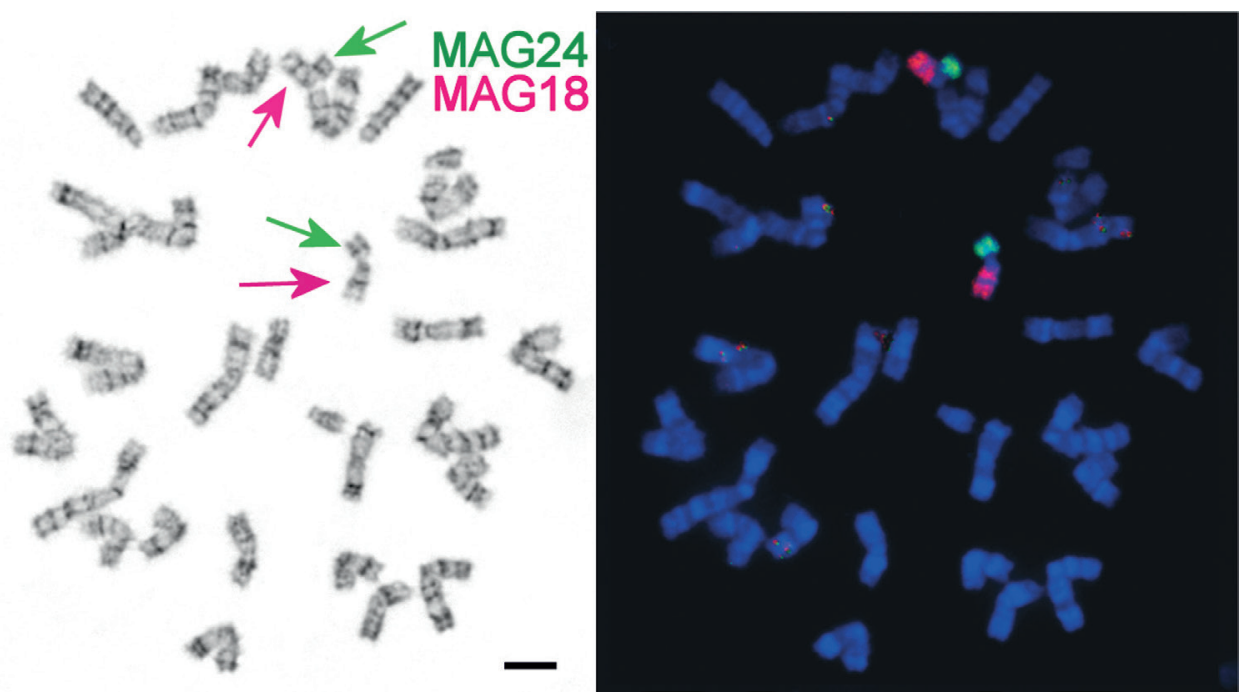

Figure 2. a G-banded E. tancrei, $2 \mathrm{n}=30(25601$ $)$ metaphase spread. b the same spread, fluorescent in situ hybridisation (Zoo-FISH) of M. agrestis (MAG) chromosome 18 (red) and 24 (green) on Rb metacentrics (red and green arrows). Bar $=10 \mu \mathrm{m}$.

\section{Discussion}

The analysis of the spatio-temporal variation in the structure of a chromosomal polymorphism zone in E. tancrei with an interval of 25 years showed that the distribution 
of chromosomal forms within the area has not changed during this period, except for a small range expansion of a low-chromosomal form $(2 n=32)$ at the western boundary (Lyapunova et al. 2010). Discovery of the chromosome form with $2 \mathrm{n}=30$ expanded the limits for chromosome rearrangements to the maximal number of fusions in $E$. tancrei, and also moved a border of the chromosomal polymorphism zone to the East, closer to the E. alaicus Vorontsov et al., 1969 range. The form with 2n = 30 may be considered as the lowest possible chromosome number for E. tancrei, because in such a karyotype only the sex chromosomes (XX, in both sexes) and one pair of acrocentric autosomes remain not rearranged. To date, whole-arm reciprocal translocations (WARTs) have not been recorded in E. tancrei. The X chromosomes clearly do not tend to be involved in $\mathrm{Rb}$ translocations; a heterozygous $2 \mathrm{n}=53$ karyotype with an $\mathrm{X}$-autosome $\mathrm{Rb}$-translocation was detected only once in a single female of $E$. tancrei from the Tien-Shan (Lyapunova et al. 1985).

Applying the Zoo-FISH method allows the detection of the homology of translocations, which are only estimated by G-banding. The new karyotype with $2 \mathrm{n}=30$ contains three $\mathrm{Rb}$ translocations (metacentrics 2, 3, 4, Fig. 1) that are homologous to fusions recently described for the $2 \mathrm{n}=48$ populations inhabiting the northern bank of the Surkhob River, approximately $100 \mathrm{~km}$ to the west. Based on these data, we suggest a common origin for these populations. Independent origin may be suggested for a population from the southern bank of the Surkhob River $(2 n=50)$, which shares monobrachial homology with the $2 \mathrm{n}=48$ form. Furthermore, a partial homology was revealed by Zoo-FISH in spite of their similar G-banding picture (Bakloushinskaya et al. 2010). This case of hidden variability requires a re-investigation of other known chromosomal forms of E. tancrei. The Pamiro-Alay is a mountain system with deep valleys and large rivers; mole voles have a mosaic pattern of distribution there. An existence in small demes with limited possibilities for spreading may provoke inbreeding and fast fixing of chromosome rearrangements (Bush et al. 1977). A subterranean way of living may enhance such a process. Speciation by monobrachial centric fusions is one of the well-documented models for house mice (Baker, Bickham 1986, Nunes et al. 2011). However, in the common shrew, the gene flow may be not affected by even extensive monobrachial homology in a hybrid zone between karyotypic races (Basset et al. 2006, Horn et al. 2012). Additional molecular cytogenetic studies are needed to clarify the homology of different chromosomal forms of E. tancrei and determine the role of different chromosome rearrangements in species evolution.

\section{Acknowledgements}

This study was funded in part by research grants from the Russian Foundation for Basic Research and Programs of the Russian Academy of Sciences (MCB and Dynamics and Conservation of Genofonds). We thank the Director of the Institute of Zoology and Parasitology of the Academy of Sciences of the Tadjik Republik, Dr. A.S. Saidov, for help in organizing the field research. 


\section{References}

Baker RJ, Bickham JW (1986) Speciation by monobrachial centric fusions. Proceedings of the National Academy of Sciences USA 83: 8245-8248. doi: 10.1073/pnas.83.21.8245

Bakloushinskaya IY, Lyapunova EA (1990) Nomenclature of chromosomes of eastern mole vole Ellobius tancrei. Tsitologia 32: 378-383. [In Russian]

Bakloushinskaya IY, Lyapunova EA (2003) History of study and evolutionary significance of wide Robertsonian variability in mole voles Ellobius tancrei s.l. (Mammalia, Rodentia) In: Kryukov AP (Ed) Problems of Evolution (5). Vladivostok, Dalnauka, 114-126.

Bakloushinskaya IYu, Romanenko SA, Graphodatsky AS, Matveevsky SN, Lyapunova EA, Kolomiets OL (2010) The role of chromosome rearrangements in the evolution of mole voles of the genus Ellobius (Rodentia, Mammalia). Russian Journal of Genetics 46 (9): 1143-1145. doi: 10.1134/S1022795410090346

Bakloushinskaya IYu, Matveevsky SN, Romanenko SA, Serdukova NA, Kolomiets OL, Spangenberg VE, Lyapunova EA, Graphodatsky AS (2012) A comparative analysis of the mole vole sibling species Ellobius tancrei and E. talpinus (Cricetidae, Rodentia) through chromosome painting and examination of synaptonemal complex structures in hybrids. Cytogenetic and Genome Research 136: 199-207. doi: 10.1159/000336459

Basset P, Yannic G, Brünner H, Hausser J (2006) Restricted gene flow at specific parts of the shrew genome in chromosomal hybrid zones. Evolution 60: 1718-1730. doi: 10.1111/ j.0014-3820.2006.tb00515.x

Bush GL, Case SM, Wilson AS, Patton JL (1977) Rapid speciation and chromosomal evolution in mammals. Proceedings of the National Academy of Sciences USA 74: 3942-3946. doi: $10.1073 /$ pnas.74.9.3942

Clare G (2012) The in vitro mammalian chromosome aberration test. Methods in Molecular Biology 817: 69-91. doi: 10.1007/978-1-61779-421-6_5

Ford CE, Hamerton JL (1956) A colchicine hypotonic citrate, squash sequence for mammalian chromosomes. Stain Technology 31: 247-251.

Ford CE, Hamerton JL, Sharman GB (1957) Chromosome polymorphism in the common shrew. Nature 180: 392-393. doi: 10.1038/180392a0

Golov BA (1954) A live trap for mole vole. Byulletin Moskovskogo Obschestva Ispytateley Prirody, Otdel Biologicheskii 59: 95-96. [In Russian]

Graphodatsky AS, Yang F, O’Brien PCM, Serdukova N, Milne BS, Trifonov V, FergusonSmith MA (2000) A comparative chromosome map of the Arctic fox, red fox and dog defined by chromosome painting and high resolution G-banding. Chromosome Research 8: 253-263. doi: 10.1023/A:1009217400140

Gropp A, Tettenborn U, von Lehmann E (1969) Chromosomenuntersuchungen bei der Tabakmaus (M. poschiavinus) und bei Tabakmaus-Hybriden. Experientia 25(8): 875-876. doi: 10.1007/BF01897931

Horn A, Basset P, Yannic G, Banaszek A, Borodin PM, Bulatova NS, Jadwiszczak K, Jones RM, Polyakov AV, Ratkiewicz M, Searle JB, Shchipanov NA, Zima J, Hausser J (2012) Chromosomal rearrangements do not seem to affect the gene flow in hybrid zones between karyotypic races of the common shrew (Sorex araneus). Evolution 66: 882-889. doi: 10.1111/j.1558-5646.2011.01478.x 
King M (1993) Species Evolution. The Role of Chromosome Change. Cambridge University Press, New York. 336 pp.

Lyapunova EA, Vorontsov NN, Korobitsina KV, Ivanitskaya EYu, Borisov YuM, Yakimenko LV, Dovgal VYe (1980) A Robertsonian fan in Ellobius talpinus. Genetica 52/53: 239_ 247. doi: 10.1007/BF00121833

Lyapunova EA, Ivnitskii SB, Korablev VP, Yanina IYu (1984) Complete Robertsonian fan of the chromosomal forms in the mole-vole superspecies Ellobius talpinus. Doklady Akademii Nauk SSSR 274: 1209-1213. [In Russian]

Lyapunova EA, Yadav D, Yanina IYu, Ivnitskii SB (1985) Genetics of mole voles (Ellobius, Rodentia): III. Independent occurrence of Robertsonian translocations of chromosomes in different populations of the superspecies Ellobius talpinus. Genetika (Moscow) 21 (9): 1503-1506. [In Russian]

Lyapunova EA, Bakloushinskaya IYu, Saidov AS, Saidov KKh (2010) Dynamics of chromosome variation in mole voles Ellobius tancrei (Mammalia, Rodentia) in Pamiro-Alay in the period from 1982 to 2008. Russian Journal of Genetics 45 (5): 566-571. doi: 10.1134/ S1022795410050091

Nunes AC, Catalan J, Lopez J, da Graça Ramalhinho M, da Luz Mathias M, Britton-Davidian J (2011) Fertility assessment in hybrids between monobrachially homologous Rb races of the house mouse from the island of Madeira: implications for modes of chromosomal evolution. Heredity 106(2): 348-356. doi: 10.1038/hdy.2010.74

Piálek J, Hauffe HC, Searle JB (2005) Chromosomal variation in the house mouse. Biological Journal of the Linnean Society 84: 535-563. doi: 10.1111/j.1095-8312.2005.00454.x

Ruiz-Herrera A, Farré M, Robinson TJ (2012) Molecular cytogenetic and genomic insights into chromosomal evolution. Heredity 108: 28-36. doi: 10.1038/hdy.2011.102

Seabright M (1971) A rapid banding technique for human chromosomes. Lancet 2: 971-972. doi: 10.1016/S0140-6736(71)90287-X

Sitnikova NA, Romanenko SA, O’Brien PCM, Perelman PL, Fu B, Rubtsova NV, Serdukova NA, Golenishchev FN, Trifonov VA, Ferguson-Smith MA, Yang F, Graphodatsky AS (2007) Chromosomal evolution of Arvicolinae (Cricetidae, Rodentia). I. The genome homology of tundra vole, field vole, mouse and golden hamster revealed by comparative chromosome painting. Chromosome Research 15: 447-456. doi: 10.1007/s10577-007-1137-y

Slijepcevic P (1998) Telomeres and mechanisms of Robertsonian fusions. Chromosoma 107: 136-140. doi: 10.1007/s004120050289

Vorontsov NN, Lyapunova EA, Zakarjan GG, Ivanov VG (1969) The karyology and taxonomy of the genus Ellobius (Microtinae, Rodentia). In: Vorontsov NN (Ed) The Mammals: Evolution, Karyology, Faunistics, Systematics. Nauka, Novosibirsk. 127-129. [in Russian] White MJD (1978) Modes of speciation. San Francisco: Freeman \& Co. 455 p.

Wójcik JM, Borodin PM, Fedyk S, Fredga K, Hausser J, Mishta A, Orlov VN, Searle JB, Volobuev VT, Zima J (2003) The list of the chromosome races of the common shrew Sorex araneus (updated 2002). Mammalia 62: 169-179. doi: 10.1515/mamm.2003.67.2.169

Yang F, O’Brien PCM, Milne BS, Graphodatsky AS, Solanky N, Trifonov V, Rens W, Sargan D, Ferguson-Smith MA (1999) A complete comparative chromosome map for the dog, red fox, and human and its integration with canine genetic maps. Genomics 62: 189-202. doi: $10.1006 /$ geno.1999.5989 